\title{
Gender Differences in Students' Perceptions of Information Technology as a Career
}

\author{
Theda Thomas and Alesha Allen \\ School of Business and Informatics, ACU National, \\ Melbourne, Australia
}

\section{theda.thomas@acu.edu.au}

\section{Executive Summary}

This paper reports on an investigation into first year students' perceptions of IT as a career. There are many stereotypes of the typical IT professional. These stereotypes are often depicted in the media and affect students' perceptions of the career and whether they should study IT or not.

An exploratory study into male and female first year students' perceptions of the IT professional is presented. The participants included students studying the Bachelor of Business and Bachelor of Information Systems degrees at ACU National in Melbourne, Australia. The study investigated the differences and similarities between the perceptions of males and females as well as where they came by those perceptions.

The study found that the majority of students had chosen to drop IT as a subject at school by Year 10 of their schooling. Males and females differ in their reasons for giving up IT, with females listing computer illiteracy and dislike of being called a nerd as their main reasons and males listing boredom, teachers not being encouraging and little creativity as their main reasons for stopping.

The students were then asked questions relating to the IT industry. A t-test showed that females were significantly more negative about the industry in their answers to three of the questions, namely "Is it 'uncool' to be interested in computers?" "Does the IT industry offer good job prospects?" and "Are people working in the IT industry 'nerds/computer geeks'?" The survey then went on to look at the technical versus non-technical issue in perceptions of an IT career. The majority of the participants believed that an IT job consists mainly of technical work and working at a computer. This was true for all the students across both genders.

The majority of students did not know any females in the IT industry and could not name any female role models from real life or from TV or film. Some of the role models that they did mention were cartoon characters.

The final part of the survey tried to determine where the students felt that their knowledge of an IT career came from. Both males and females choose schooling, friends and

Material published as part of this journal, either on-line or in print, is copyrighted by the Informing Science Institute. Permission to make digital or paper copy of part or all of these works for personal or classroom use is granted without fee provided that the copies are not made or distributed for profit or commercial advantage AND that copies 1) bear this notice in full and 2) give the full citation on the first page. It is permissible to abstract these works so long as credit is given. To copy in all other cases or to republish or to post on a server or to redistribute to lists requires specific permission and payment of a fee. Contact Publisher@InformingScience.org to request redistribution permission. the media as their main sources of knowledge of the area. It is interesting to note that although there were no significant differences in where they gained their perceptions, the perceptions themselves were different.

The research is explorative but, if the findings are found to be true, then there 
are some methods that might help to address the problem of females not choosing an IT career. The first recommendation is that the problem needs to be tackled in the early years - primary and lower secondary school. As students say that much of their knowledge of IT as a career comes from school, the school curriculum should be looked at to determine if it is suitable for both sexes. This could include the curriculum itself or the way in which it is taught and assessed. Another avenue that could be addressed is way in which computer personnel are depicted in the media. Girls' magazines that target the early teen market could be used by Computer Societies to raise the profile of girls seeing technology as fun, worthwhile and a job that they might consider. This could be done through sponsoring activities, advertisements or games.

The research is limited in its generalizability and further research will need to be done to determine how to address the issues raised.

Keywords: gender issues in IT, perceptions of IT.

\section{Introduction}

There has long been an awareness that the number of women in Information Technology (IT) is low compared to men. The percentage of women gaining degrees in computing in the United States went down from $32.5 \%$ in 1980 to $28 \%$ in 2000 (Camp, 2002). In Australia, the percentage of women enrolling in IT courses has dropped from 48.1\% in 1994 to 32\% in 2003 (Lang \& Hede, 2004) and dropped to $21.97 \%$ in 2005 (O'Keefe, 2005). These are alarming figures. This drop is occurring despite some women IT professionals describing their work as: "challenging; varied; and providing opportunities to meet people, to travel, and to work at home" (Teague, 2002, p.148).

This paper investigates the perceptions that potential students who come into tertiary education have of IT as a career and where they get those perceptions. The findings are used to suggest that the problem needs to be addressed at a young age rather than waiting until students reach tertiary education.

\section{Perceptions of IT as a Career}

This section does not try to be exhaustive on perceptions of IT as a career, but will highlight some of the perceptions that may be leading to fewer women choosing IT as a career.

\section{Perception: The Stereotypical IT Nerd}

Kim Roy (cited in O'Keefe, 2005) stated that “... In terms of attracting women, the simplistic approach is the fact that IT still has that geeky, computer nerd image attached...". Webster's Unabridged Thesaurus states that the definition of a "nerd" is "a boring, dull or unattractive person"; this definition itself seems to be a stereotype. Teenagers studying mathematics and science classes are often labeled as being "nerdy" and this is an adverse stereotype for IT since these subjects are often prerequisites to careers in the IT and Computer Science field (Jepson \& Perl, 2002). The image of computer nerd is one that women especially, seek to avoid (Joshi \& Kuhn, 2001, p.121).

The media is one player that is exacerbating this problem. Television and movies continue to depict the IT professional as a nerd, who has no people skills and is only concerned with technical issues. Consequently young people do not think of the IT profession as being "cool" and social pressure may dissuade women from pursuing IT as a career. 


\section{Perception: IT is a Career for Males}

IT is seen as a career for men. There are many reasons for this, some part of the reality and some perpetuated by the media.

An IT career often includes long, unpredictable hours, which may not suit a working mother. "Women are believed to value lifestyle integration and work-family balance to a greater degree then men" (Joshi \& Kuhn, 2001, p.122). Johnson and Miller (2002) maintain that there is evidence that working long hours reduces software quality. They contend that long hours should not be mandatory or necessary and that reducing hours could attract women to the job.

It is also difficult for anyone to re-enter the IT workforce after a period of absence. A mother, who may have taken a short break from the IT industry to concentrate on starting a family, may find it difficult to return to the industry because it is always changing. Companies are, more often than not, male dominated at a policy making level, and often do not implement the necessary procedures required to deal with and support women who are planning on having children or reentering the workforce (Cottrell, 1992).

The media also plays a role in emphasizing this perception of IT as male dominated. A study conducted by Lang and Hede in 2004, analyzed two computer magazines in Australia, as well as two "in-demand" teenage girl magazines over a period of a year. Lang and Hede reported that in the computer magazines males and females were depicted evenly, however in the teenage girl magazines there was no depiction of computer use at all.

Not only is there evidence of stereotypical representations in magazines, but it is also evident in video/computer games. It is easy to assume that video/computer games provide many children with an introduction to the current computer culture, and with perhaps a few exceptions, males tend to design video games for males. Jepson and Perl (2002) report on a sample of 100 video games. They claim that $92 \%$ had no female roles and of the remaining $8 \%, 6 \%$ had females playing damsel in distress roles. Games like Tomb Raider are a notable exception to this trend.

A further problem is the lack of female role models in IT. This lack is evident in the real world as well as in the media. Pearl et al. (2002) state in their report that, while students/young adults can benefit and successfully learn from mentors of either gender, women need to be exposed to female role models.

From an early age, children watch TV programs and form a liking and admiration for the key characters. Adolescence sets in and these characters are now classified as "not cool", then new programs are watched, and new key characters are idolized. This is the stage where the adolescence needs to be presented with a character that is involved with computers. It would be great if the character doesn't follow the "geek" stereotype of a skinny male with glasses, stuttering when ever he talks, however, this stereotype is often shown (Joshi \& Kuhn, 2001).

IT women characters are hardly ever shown in movies or television, and when they are presented, they are portrayed in an unfavorable manner. An example could be the spooky looking "Goth girl" Abbey from the popular American series 'NCIS.' In another example, there is Sandra Bullock who stared in the Hollywood movie 'The Net'. Sandra's character is portrayed as a nerd who experiences a life-or-death drama caused by the fact that she works in an IT career. Once again, the presence of a female involved in IT is not positive.

When potential young female IT students are looking to the media for role models and inspiration, there are none available, or on the other hand the characters presented turn the student away from studying IT. Through these actions the media is perpetuating the gendered nature of IT (Lang \& Hede, 2004, p.4). 


\section{Perception: The IT Profession is only Technically Oriented}

An IT career has always included the necessity to work in teams and work with users. As users have become more computer literate, their involvement has increased as has the necessity for IT professionals to improve their interpersonal and communication skills. The idea of the computer professional working long hours in isolation is clearly not true, but this stereotype is still prevalent.

The IT industry includes many career paths, for example, business analyst, software engineer, network engineer or hardware engineering. Some of these are very technically oriented, but most still require the person to be able to work in a team and have good interpersonal skills.

The IT industry commonly advertises for employees with high academic achievement; however interpersonal skills have been shown to be an important predictor of performance (Gallivan, Truex, \& Kvasny, 2002). Systems Analysts with soft skills improve the employees' ability to collect and understand information and ability to network effectively within the organisation.

Females develop social skills consistently faster than males even at an early age (deBare, 1996). Galpin's report (2002) states that IT is gradually moving into the direction of soft skills equalling the importance of hard skills; therefore one would expect more women to be partaking in the industry.

An example of this is the Simon Fraser University (SFU) in Canada, where the participation rate of women in undergraduate IT courses has been reported to be less than $20 \%$ in 2000 . However, in courses that focus purely on the social aspects of technology, the participation rate of women is $70 \%$ (Cameron, 2000). The professors at SFU believe that the socio-technical approach will work as an important device in increasing the participation of women as IT workers, and from looking at the statistics; it seems this approach is one answer to attracting women to the industry.

Once again the portrayal of IT professionals in the media tends to show them hacking into computers, tracking satellites and other technical pastimes. Rarely, if ever, would the social side of the IT profession play a role in TV or other media.

When girls are using computers in their school years, they claim that they enjoy using chat rooms, e-mailing and surfing the web for fun (Holmes-Rowell et al., 2003; Jepson \& Perl, 2002). These are the more interpersonal activities involving a computer.

The question must also be asked if the technical bias is being perpetuated in schools. As part of our research, the school syllabus for Victoria (a state of Australia) was studied ("Victorian curriculum and assessment authority," 2004). The syllabus showed an overwhelming bias towards learning technical skills and very little on the use of computers for social activities or the need for working in teams. There is therefore little to attract the female secondary school student to the study of IT.

\section{The Research}

The research is exploratory in nature and ideas for future research are presented in the conclusion.

\section{Research Questions}

The research questions we want to explore in this paper are:

(i) Do males and females have different perceptions about IT as a career?

(ii) Do students have misconceptions about IT as a career that may be deterring females from choosing IT? 
(iii) Do males and females have different ways of gaining perceptions about IT as a career?

The questions will lead us to speculate as to how we can influence those sources of these perceptions.

\section{Research Method}

The method used for exploring these questions was a survey. The survey consisted of mostly quantitative questions, with some qualitative responses asking for clarity. The survey was undertaken with 114 first year students doing the Bachelor of Business and the Bachelor of Information Systems at ACU National in Melbourne. Ninety-eight of the 114 students responded giving a participation rate of $85.9 \%$.

The students were selected as the sample group because they represent a cross-section of students who have and have not chosen Information Systems as their career. Some of them will have chosen their major whereas others would still be choosing their major. This sample group therefore holds relevance to the research question, as to whether or not the students' perceptions of IT will deter or have deterred them from choosing the discipline as their major. The sample was one of convenience and cannot be deemed to be representative of all students studying at university. This is why the study is exploratory in nature and further study would be needed before the results could be generalized. The study was approved by the Human Research Ethics Committee of ACU National.

The first section of the survey consisted of demographic questions. The only demographic data that will be used for this paper is the students' gender and whether they have chosen an IS major or not. This was followed by questions on whether and when the student gave up studying IT at school and their reasons for stopping. They were then asked for their perceptions of an IT career and of women in the IT industry. The last section relevant to this paper covered questions on where the students gained their knowledge of an IT career.

\section{Research Results}

\section{Demographic Data}

There were 114 students who were taking the Bachelor of Information Systems or Bachelor of Business at ACU National in 2005. A sample size of 114 students were administered the survey, and $85.9 \%$ of these students completed the survey. Of the 98 students who participated in this study, $63.3 \%$ were male and the remaining $36.7 \%$ were female (Table 1 ). The skewing of the population towards males may be problematic in generalizing the results.

Only 31 (31.6\%) of students had chosen to study an Information Systems major by doing the Bachelor of Information Systems or the Bachelor of Business / Information Systems. Only 11 of the 31 were female (35.5\%). While this is higher than the national average of $21.97 \%$, it is still low. (See Table 1.) It is interesting to note that there seems to be the same gender inequality with the Business courses as there is with the Information Systems course - at least at ACU National. 
Table 1: Information Systems Major (by Gender)

\begin{tabular}{|c|c|c|c|c|c|c|}
\hline \multirow[b]{2}{*}{ Major * Gender } & \multicolumn{4}{|c|}{ Gender } & \multicolumn{2}{|c|}{ Total } \\
\hline & $\begin{array}{l}\text { Male } \\
\mathrm{N}\end{array}$ & $\%$ & $\begin{array}{l}\text { Female } \\
\mathrm{N}\end{array}$ & $\%$ & $\mathrm{~N}$ & $\%$ \\
\hline Non IS Major & 42 & $62.6 \%$ & 25 & $37.4 \%$ & 67 & $100 \%$ \\
\hline IS Major & 20 & $64.5 \%$ & 11 & $35.5 \%$ & 31 & $100 \%$ \\
\hline Total & 62 & $63.3 \%$ & 36 & $36.7 \%$ & 98 & $100 \%$ \\
\hline
\end{tabular}

\section{IT at Secondary School}

Table 2 shows when students had stopped studying IT, $62.6 \%$ of the participants had stopped studying by the end of Year 10 . There were $69.5 \%$ of females who stopped studying IT by the end of Year 10 compared to $51.3 \%$ of males. In Australia students go to school for 12 years meaning that most students stop studying IT at least 2 years before they finish secondary school.

Table 2: Last studied IT at secondary school

\begin{tabular}{|c|c|c|c|c|c|c|c|}
\hline $\begin{array}{l}\text { Last studied } \\
\text { IT }\end{array}$ & Male & Percent & Female & Percent & $\begin{array}{c}\text { Total } \\
\text { Frequency }\end{array}$ & $\begin{array}{c}\text { Total } \\
\text { Percent }\end{array}$ & $\begin{array}{c}\text { Cumulative } \\
\text { Percent }\end{array}$ \\
\hline Year 9 & 7 & 11.3 & 1 & 2.8 & 8 & 8.2 & 8.8 \\
\hline Year 10 & 25 & 40.3 & 24 & 66.7 & 49 & 50.0 & 58.2 \\
\hline Year 11 & 12 & 19.3 & 3 & 8.3 & 15 & 15.3 & 63.5 \\
\hline Year 12 & 14 & 22.6 & 5 & 13.9 & 19 & 19.4 & 92.9 \\
\hline Total & 58 & 93.5 & 33 & 91.7 & 91 & 92.9 & \\
\hline
\end{tabular}

The students were then asked to say why they stopped studying IT in an open-ended discussion question. There responses are categorized in Table 3.

It was interesting to note the differences in the reasons that the males and females gave for giving up IT at school. The results showed that $85.7 \%$ of the female participants felt that they discontinued studying IT in secondary school because they '.. didn't want to be classified a nerd' $(32.1 \%)$ or that they were '... computer illiterate' $(53.6 \%)$, whilst $62.2 \%$ of the male participants stated that they discontinued studying IT because '.. teachers weren't encouraging' $(15.6 \%)$, '... not a creative environment' $(22.2 \%)$ and that IT ' $\ldots$ was boring' $(24.4 \%)$. 
Table 3: Why students stopped studying IT before Year 12 - by gender

\begin{tabular}{|c|c|c|c|c|c|c|}
\hline \multirow{3}{*}{$\begin{array}{l}\text { Reasons for why students } \\
\text { stopped studying IT before Year } \\
12\end{array}$} & \multicolumn{4}{|c|}{ Gender } & \multicolumn{2}{|c|}{ Total } \\
\hline & \multicolumn{2}{|c|}{ Male } & \multicolumn{2}{|c|}{ female } & & \\
\hline & $\mathrm{N}$ & $\%$ & $\mathrm{~N}$ & $\%$ & $\mathrm{~N}$ & $\%$ \\
\hline Computer illiterate & 4 & $8.9 \%$ & 15 & $53.6 \%$ & 19 & $26.0 \%$ \\
\hline $\begin{array}{l}\text { Didn't want to be classified a } \\
\text { "nerd" }\end{array}$ & 6 & $13.3 \%$ & 9 & $32.1 \%$ & 15 & $20.5 \%$ \\
\hline Too boring & 11 & $24.4 \%$ & 1 & $3.6 \%$ & 12 & $16.4 \%$ \\
\hline Not a creative environment & 10 & $22.2 \%$ & 1 & $3.6 \%$ & 11 & $15.1 \%$ \\
\hline Teachers weren't encouraging & 7 & $15.6 \%$ & 1 & $3.6 \%$ & 8 & $11.0 \%$ \\
\hline Didn't think it was necessary & 3 & $6.7 \%$ & 1 & $3.6 \%$ & 4 & $5.5 \%$ \\
\hline Wasn't offered & 4 & $8.9 \%$ & 0 & $.0 \%$ & 4 & $5.5 \%$ \\
\hline Total & 45 & $100 \%$ & 28 & $100 \%$ & 73 & $100 \%$ \\
\hline
\end{tabular}

A question that arises from this study and could be explored further is: "Could the technical nature of the IT syllabus at Year 9 and 10 level be one of the factors that is influencing the girls' perceptions of IT and causing themselves to label themselves as computer illiterate?"

\section{Perceptions of IT as a Career}

Participants were asked to rate four aspects of IT as a career using a Likert scale with one representing 'definitely' and five 'definitely not'. This means that the lower the mean score, the more the students think the question is true. These results for males and females are shown in Table 4.

The total mean scores of each perception ranges from 2.45 to 3.65 , indicates that there is little difference between the perceptions overall.

The means of the participants' responses to a set of general perceptions show that males and females seemed to hold different understandings and opinions of some of the statements. For example, the mean values of both male (4.37) and female (2.42) participants for whether it is "uncool" to be interested in computers are very different. As a result, the mean values indicate that the female participants were more likely to respond that it is "uncool" to be interested in computers.

This was further tested using the Levene's test for equality of variances and t-test results (Table 4). Levene's test shows whether the two groups have approximately equal variance on the dependent variable. The significance for whether IT jobs pay big salaries and whether IT people are "geeks" has values of .681 and .348 , both greater than .01. Therefore these variances (males and female participants) are approximately equal. While the results for both whether IT is "uncool" (.007) and whether the IT industry offers good prospects, (.000) shows great significance between the variances. Table 4 also shows the results of the independent samples t-test. 
Table 4: Students' perceptions of IT as a career

\begin{tabular}{|c|c|c|c|c|c|c|c|c|c|}
\hline & \multicolumn{3}{|c|}{$\begin{array}{l}\text { Means and Standard } \\
\text { Deviations (Likert Scale 1-5) }\end{array}$} & & \multicolumn{2}{|c|}{$\begin{array}{l}\text { Levene's Test } \\
\text { for Equality of } \\
\text { Variances }\end{array}$} & \multicolumn{3}{|l|}{ T-test } \\
\hline & $\begin{array}{l}\text { Male } \\
\mathrm{N}=62\end{array}$ & $\begin{array}{l}\text { Female } \\
\mathrm{N}=36\end{array}$ & $\begin{array}{l}\text { Total } \\
\mathrm{N}=98\end{array}$ & & $\mathrm{~F}$ & Sig. & $\mathrm{t}$ & $\begin{array}{l}\text { Sig. } \\
\text { (2-tail) }\end{array}$ & $\begin{array}{l}\text { Std. } \\
\text { Error } \\
\text { Diff }\end{array}$ \\
\hline & $\begin{array}{l}\text { Mean } \\
(\mathrm{sd})\end{array}$ & $\begin{array}{l}\text { Mean } \\
(\mathrm{sd})\end{array}$ & $\begin{array}{l}\text { Mean } \\
\text { (sd) }\end{array}$ & & & & & & \\
\hline \multirow[t]{2}{*}{$\begin{array}{l}\text { Do IT jobs pay big } \\
\text { salaries? }\end{array}$} & $\begin{array}{l}2.35 \\
(.812)\end{array}$ & $\begin{array}{l}2.61 \\
(.903)\end{array}$ & $\begin{array}{l}2.45 \\
(.851)\end{array}$ & EQA* & .171 & .681 & -1.445 & .152 & .177 \\
\hline & & & & EQNA* & & & -1.405 & .165 & .182 \\
\hline \multirow[t]{2}{*}{$\begin{array}{l}\text { Is it "uncool" to be } \\
\text { interested in com- } \\
\text { puters? }\end{array}$} & $\begin{array}{l}4.37 \\
(1.012)\end{array}$ & $\begin{array}{l}2.42 \\
(1.402)\end{array}$ & $\begin{array}{l}3.65 \\
(1.500)\end{array}$ & EQA* & 7.544 & .007 & 7.977 & .000 & .245 \\
\hline & & & & EQNA* & & & 7.330 & .000 & .267 \\
\hline \multirow[t]{2}{*}{$\begin{array}{l}\text { Does the IT industry } \\
\text { offer good job pros- } \\
\text { pects? }\end{array}$} & $\begin{array}{l}1.85 \\
(.807)\end{array}$ & $\begin{array}{l}3.64 \\
(1.199)\end{array}$ & $\begin{array}{l}2.51 \\
(1.294)\end{array}$ & EQA* & 16.705 & .000 & -8.793 & .000 & .203 \\
\hline & & & & EQNA* & & & -7.945 & .000 & .225 \\
\hline \multirow[t]{2}{*}{$\begin{array}{l}\text { Are people working } \\
\text { in the IT industry } \\
\text { "nerds/computer } \\
\text { geeks?" }\end{array}$} & $\begin{array}{l}4.16 \\
(1.043)\end{array}$ & $\begin{array}{l}2.19 \\
(1.191)\end{array}$ & $\begin{array}{l}3.44 \\
(1.451)\end{array}$ & EQA* & .888 & .348 & 8.538 & .000 & .230 \\
\hline & & & & EQNA* & & & 8.242 & .000 & .239 \\
\hline
\end{tabular}

$* \mathrm{EQA}=$ Equal variances assumed, $\mathrm{EQNA}=$ Equal variances not assumed

The t-test shows that there is significant difference $(<0.01)$ in three of the questions, namely "Is it uncool" to be interested in computers?" "Does the IT industry offer good job prospects?" and "Are people working in the IT industry "nerds/computer geeks'?" Females were far more negative than males in answering these three questions.

These results would indicate that, at least in the aspects given above, females have a significantly different image of computing as a career. The results also show that their image is more negative than their male counterparts.

The survey then went on to look at the technical versus non-technical issue in perceptions of an IT career. Table 5 presents the mean values of the participants' responses question on how much of an IT job is devoted to certain tasks. One represented '10\%' while six represents ' $100 \%$ '. It is evident by analyzing the mean values that both males and females hold similar perceptions of an IT career. This was also found to be true using Levene's Test and the t-test (as shown in Table 5.)

The majority of the participants believed that an IT job consists mainly of technical work and working at a computer. This was true for all the students across both genders. Although the perceptions of this aspect did not differ significantly between the genders, the stereotypical perceptions of IT as a career were significantly different. 
Table 5: Students' perceptions of the technical nature of IT as a career

\begin{tabular}{|c|c|c|c|c|c|c|c|c|c|}
\hline & \multicolumn{3}{|c|}{$\begin{array}{l}\text { Means and Standard } \\
\text { Deviations (Likert Scale 1-5) }\end{array}$} & & \multicolumn{2}{|c|}{$\begin{array}{l}\text { Levene's Test } \\
\text { for Equality of } \\
\text { Variances }\end{array}$} & \multicolumn{3}{|l|}{ T-test } \\
\hline & $\begin{array}{l}\text { Male } \\
\mathrm{N}=62\end{array}$ & $\begin{array}{l}\text { Female } \\
\mathrm{N}=36\end{array}$ & $\begin{array}{l}\text { Total } \\
\mathrm{N}=98\end{array}$ & & $\mathrm{~F}$ & Sig. & $\mathrm{t}$ & $\begin{array}{l}\text { Sig. } \\
(2 \text {-tail) }\end{array}$ & $\begin{array}{l}\text { Std. } \\
\text { Error } \\
\text { Diff }\end{array}$ \\
\hline & $\begin{array}{l}\text { Mean } \\
(\mathrm{sd})\end{array}$ & $\begin{array}{l}\text { Mean } \\
\text { (sd) }\end{array}$ & $\begin{array}{l}\text { Mean } \\
(\mathrm{sd})\end{array}$ & & & & & & \\
\hline \multirow[t]{2}{*}{$\begin{array}{l}\text { How much of an IT } \\
\text { job is working at a } \\
\text { computer? }\end{array}$} & $\begin{array}{l}4.13 \\
(1.123)\end{array}$ & $\begin{array}{l}4.20 \\
(1.158)\end{array}$ & $\begin{array}{l}4.15 \\
(1.130)\end{array}$ & EQA* & .278 & .599 & -.296 & .768 & .240 \\
\hline & & & & EQNA* & & & -.293 & .770 & .242 \\
\hline \multirow[t]{2}{*}{$\begin{array}{l}\text { How much of an IT } \\
\text { job is working in } \\
\text { teams? }\end{array}$} & $\begin{array}{l}3.31 \\
(1.362)\end{array}$ & $\begin{array}{l}2.83 \\
(1.320)\end{array}$ & $\begin{array}{l}3.13 \\
(1.359)\end{array}$ & EQA* & .062 & .804 & 1.676 & .097 & .282 \\
\hline & & & & EQNA* & & & 1.690 & .095 & .280 \\
\hline \multirow[t]{2}{*}{$\begin{array}{l}\text { How much of an IT } \\
\text { job is technical work? }\end{array}$} & $\begin{array}{l}4.61 \\
(1.395)\end{array}$ & $\begin{array}{l}4.56 \\
(1.157)\end{array}$ & $\begin{array}{l}4.59 \\
(1.307)\end{array}$ & EQA* & 1.332 & .251 & .208 & .835 & .275 \\
\hline & & & & EQNA* & & & .219 & .827 & .262 \\
\hline $\begin{array}{l}\text { How much of an IT } \\
\text { job is working with } \\
\text { people? }\end{array}$ & $\begin{array}{l}2.69 \\
(1.386)\end{array}$ & $\begin{array}{l}2.42 \\
(1.251)\end{array}$ & $\begin{array}{l}2.59 \\
(1.338)\end{array}$ & EQA* & .988 & .323 & .987 & .326 & .280 \\
\hline $\begin{array}{l}\text { How much of an IT } \\
\text { job is problem solv- } \\
\text { ing? }\end{array}$ & $\begin{array}{l}3.68 \\
(1.364)\end{array}$ & $\begin{array}{l}3.75 \\
(1.422)\end{array}$ & $\begin{array}{l}3.70 \\
(1.379)\end{array}$ & $\begin{array}{l}\text { EQNA* } \\
\text { EQA* }\end{array}$ & .076 & .784 & $\begin{array}{l}1.015 \\
-.250\end{array}$ & .313 & .273 \\
\hline & & & & EQNA* & & & -.247 & .805 & .294 \\
\hline
\end{tabular}

*EQA $=$ Equal variances assumed, $\mathrm{EQNA}=$ Equal variances not assumed

Research Question One: Do males and females have different perceptions about IT as a career?

The results have shown that females have significantly different perspectives relating to the image of computing from their male counterparts. They are more negative, thinking it is "uncool" or that IT professionals are nerds or geeks. They are also significantly more negative about job prospects. Both males and females have similar perceptions about IT in terms of how much interaction they would have with people and how much is technical. Both, however, feel that the industry is predominantly technically orientated.

\section{Perceptions of Women in IT}

Participants were asked whether they know, or can name any women who work in IT. This was an open-ended question. In hindsight the research could have been improved if we also asked students about male role models as well. This could be included if this exploratory study were taken further. Table 6 shows that $59.2 \%$ of the participants wrote that didn't know any women who work in the IT industry. 
Table 6: Knowledge of women working in IT

Question: Do you know any women that work in IT?

\begin{tabular}{|c|c|c|}
\hline Knowledge of Women who work in IT & Frequency & Percent \\
\hline Don't know any & 58 & 59.2 \\
\hline A Lecturer at $\mathrm{ACU}$ & 20 & 20.4 \\
\hline Relative - Business & 13 & 13.3 \\
\hline Technical Support & 5 & 5.1 \\
\hline Total & 96 & 98.0 \\
\hline Missing & 2 & 2.0 \\
\hline Total & 98 & 100.0 \\
\hline
\end{tabular}

Participants were then asked if they knew of any women role models depicted in the media. Table 7 shows that $56.1 \%$ stated they did not know of any women IT role models - even from the media. Eight of the answers given $(8.2 \%)$ by the participants were cartoon characters (marked with an asterix). The fact that these participants were only able to name cartoon characters as their significant IT women role models, gives creditability to the assumption that (real-life) IT women characters are hardly ever shown in movies or television.

Table 7: IT role models from the media listed by the students

Question: Can you name any significant IT woman role models? (From TV, movies or real life-you may describe them if you do not know the person's name.)

\begin{tabular}{|l|l|l|}
\hline IT Women Role Models Listed by the Students & Frequency & Percent \\
\hline Don't know any & 55 & 56.1 \\
Sandra Bullock (The Net, Murder by Numbers) & 9 & 9.2 \\
Angelina Jolie (Hackers) & 8 & 8.2 \\
Miss Megabyte (Good Morning Australia) & 7 & 7.1 \\
NCIS girl & 5 & 5.1 \\
Penny (Inspector Gadget)* & 5 & 5.1 \\
Charlie's Angels & 4 & 4.1 \\
Velma (Scooby Doo)* & 3 & 3.1 \\
\hline Total & 96 & 98.0 \\
\hline
\end{tabular}

* Cartoon characters

Combining the data from the previous section with the data showing the students' perceptions of women in IT, we are able to answer the second research question.

Research Question Two: Do students have misconceptions about IT as a career that may be deterring females from studying IT?

This question has not fully been answered by this study. There are indications that there are misconceptions that may be deterring students. For example, the students all felt that the job was 
very technical (as discussed in the previous section.) The females especially felt that the job was "nerdy" and "uncool". The students' inability to name female role models or examples would support the idea that the career is male dominated. The latter may not be a misconception, however, but might be reality.

Table 8: Sources of students' perceptions of IT as a career

\begin{tabular}{|c|c|c|c|c|c|c|c|c|c|}
\hline & \multicolumn{3}{|c|}{$\begin{array}{l}\text { Means and Standard } \\
\text { Deviations (Likert Scale 1-5) }\end{array}$} & & \multicolumn{2}{|c|}{$\begin{array}{l}\text { Levene's Test } \\
\text { for Equality of } \\
\text { Variances }\end{array}$} & \multicolumn{3}{|l|}{ T-test } \\
\hline & $\begin{array}{l}\text { Male } \\
\mathrm{N}=62\end{array}$ & $\begin{array}{l}\text { Female } \\
\mathrm{N}=36\end{array}$ & $\begin{array}{l}\text { Total } \\
\mathrm{N}=98\end{array}$ & & $\mathrm{~F}$ & Sig. & $\mathrm{t}$ & $\begin{array}{l}\text { Sig. } \\
(2 \text {-tail) }\end{array}$ & $\begin{array}{l}\text { Std. } \\
\text { Error } \\
\text { Diff }\end{array}$ \\
\hline & $\begin{array}{l}\text { Mean } \\
\text { (sd) }\end{array}$ & $\begin{array}{l}\text { Mean } \\
\text { (sd) }\end{array}$ & $\begin{array}{l}\text { Mean } \\
\text { (sd) }\end{array}$ & & & & & & \\
\hline \multirow[t]{2}{*}{$\begin{array}{l}\text { Does your knowl- } \\
\text { edge of IT come } \\
\text { from your friends? }\end{array}$} & $\begin{array}{l}2.40 \\
(1.221)\end{array}$ & $\begin{array}{l}2.61 \\
(1.420)\end{array}$ & $\begin{array}{l}2.48 \\
(1.294)\end{array}$ & EQA* & 1.207 & .275 & -.765 & .446 & .272 \\
\hline & & & & EQNA* & & & -.735 & .465 & .283 \\
\hline \multirow[t]{2}{*}{$\begin{array}{l}\text { Does your knowl- } \\
\text { edge of IT come } \\
\text { from the media? }\end{array}$} & $\begin{array}{l}2.52 \\
(1.565)\end{array}$ & $\begin{array}{l}2.56 \\
(1.423)\end{array}$ & $\begin{array}{l}2.53 \\
(1.507)\end{array}$ & EQA* & 1.047 & .309 & -.124 & .901 & .317 \\
\hline & & & & EQNA* & & & -.127 & .899 & .309 \\
\hline \multirow[t]{2}{*}{$\begin{array}{l}\text { Does your knowl- } \\
\text { edge of IT come } \\
\text { from school IT } \\
\text { courses? }\end{array}$} & $\begin{array}{l}2.27 \\
(1.133)\end{array}$ & $\begin{array}{l}2.03 \\
(1.000)\end{array}$ & $\begin{array}{l}2.18 \\
(1.087)\end{array}$ & EQA* & 1.824 & .180 & 1.082 & .282 & .228 \\
\hline & & & & EQNA* & & & 1.119 & .266 & .220 \\
\hline \multirow[t]{2}{*}{$\begin{array}{l}\text { Does your knowl- } \\
\text { edge of IT come } \\
\text { from your career } \\
\text { counselor? }\end{array}$} & $\begin{array}{l}4.16 \\
(1.369)\end{array}$ & $\begin{array}{l}4.67 \\
(1.331)\end{array}$ & $\begin{array}{l}4.35 \\
(1.371)\end{array}$ & EQA* & .619 & .433 & -1.779 & .078 & .284 \\
\hline & & & & EQNA* & & & -1.793 & .077 & .282 \\
\hline \multirow[t]{2}{*}{$\begin{array}{l}\text { Does your knowl- } \\
\text { edge of IT come } \\
\text { from your family? }\end{array}$} & $\begin{array}{l}4.79 \\
(1.230)\end{array}$ & $\begin{array}{l}4.97 \\
(.910)\end{array}$ & $\begin{array}{l}4.86 \\
(1.121)\end{array}$ & EQA* & 1.809 & .182 & -.772 & .442 & .235 \\
\hline & & & & EQNA* & & & -.836 & .406 & .218 \\
\hline \multirow[t]{2}{*}{$\begin{array}{l}\text { Does your knowl- } \\
\text { edge of IT come } \\
\text { from university IT } \\
\text { courses? }\end{array}$} & $\begin{array}{l}4.85 \\
(1.199)\end{array}$ & $\begin{array}{l}4.53 \\
(1.082)\end{array}$ & $\begin{array}{l}4.73 \\
(1.163)\end{array}$ & EQA* & .262 & .610 & 1.348 & .181 & .243 \\
\hline & & & & EQNA* & & & 1.386 & .170 & .236 \\
\hline
\end{tabular}

$* \mathrm{EQA}=$ Equal variances assumed, $\mathrm{EQNA}=$ Equal variances not assumed

\section{Sources of Perceptions}

The next question of interest was where the students' perceptions of IT came from. The participants were asked to number options such as media, school, friends etc in the order of ' 1 ' onwards. (Listing ' 1 ' as the most influential source.) This means that the lower the mean the more influential the source. Table 8 gives the results. The most influential was school IT courses, (2.18) fol- 
lowed by friends (2.48) and media (2.53). While school career counselors (4.35), university IT courses (4.73) and family (4.86) were much lower.

The differences in the students' perceptions were not found to be significantly different using Levene's test and the t-test (Table 8). It is interesting to note that while males and females show media to be the second-most influential in giving their perceptions of IT, the literature has shown that media is very male-oriented and that female magazines for teenagers print very little about computers.

Research Question Three: Do males and females have different ways of gaining perceptions about IT as a career?

Our results show that both males and females gain their perceptions from the same main sources. These are friends, school and the media.

\section{Summary of Research Findings}

The limitations of the sample make this an exploratory study only. There are indications in the results that show that students are being turned away from IT during their middle school years rather than when choosing a university course. By Year 10, 69.3\% of females and 53.1\% of males had given up the study of IT. Males and females differ in their reasons for giving up IT, with females listing computer illiteracy and dislike of being called a nerd as their main reasons and males listing boredom, teachers not being encouraging and little creativity as their main reasons for stopping.

Both groups felt that they got their perceptions came mainly from school, the media and friends. When one considers that $56.1 \%$ could not name a woman role model depicted in the media and another $8 \%$ chose cartoon characters, the fact that media is the students' second most likely source of their perceptions is a little alarming. This problem has also been explored in the literature where it has been shown that teenage girls' magazines rarely depict anyone using a computer or even run computer adverts.

Few of the students could point to real life women in IT roles, either. There were $59.2 \%$ who could not name any and a further $20.4 \%$ who named an IT lecturer at the university. This left only $18.4 \%$ who could name a female that they knew in the IT industry.

\section{Recommendations}

It would seem that students, both male and female are dropping out of IT courses in their middle years of Secondary School. This means that the problem needs to be addressed in primary and lower secondary school rather than trying to attract students when they get to university level.

The students identified the sources of their perceptions as being school, media and their friends. If we assume that the students' friends are watching the same programs, reading the same magazines and attending the same schools as the students themselves then the two areas that need addressing when changing students' perceptions are the schools and media.

The recommendations that follow are very tentative, but will hopefully provide food for thought.

\section{Recommendations for Educators}

School is also very influential in students' perceptions of IT as a career. A quick study of the school syllabus in Victoria, Australia showed that it is highly biased towards teaching technical computer skills, especially up to Year 10. Little emphasis is put on letting the students use the computer for more social activities that girls might enjoy more or for promoting the team activities that would be required in a career in IT. 
An in-depth investigation into the school syllabus and the way in which IT is taught at school could show whether the syllabus and teaching is turning students, especially girls, away from IT as a career. The lower secondary school syllabus in Australia seems to be focused on teaching the students IT technical skills with some study units assigned to IT skills related to communication, like email and PowerPoint. Teachers and curriculum developers should investigate the many aspects of an IT career and try to incorporate some of the activities that girls might find fun. IT can be used to facilitate group activities though group decision support systems, discussion groups, chat rooms and email. These are all activities that Holmes-Rowell et al. (2003) and Jepson and Perl (2002) say that girls enjoy using.

At tertiary level, the courses need to be made accessible and interesting for both males and females. The Simon Fraser University (SFU) in Canada has found that by moving to a sociotechnical approach to IT, the participation rate of women has risen to be as high as $70 \%$. The literature has shown that "soft skills" are important in IT graduates, which means that it makes sense to incorporate these skills into our courses.

\section{Recommendations for Computer Societies}

One cannot expect the media to change their magazines, TV programs or films without incentives. The students in our study said that the media was one of the greatest influences on their perceptions of an IT career and yet the literature shows that females are not subjected to computer advertisements or female role models through the media to the same extent as males.

Computer Societies should put some work into reaching young adolescence, and in particular, adolescent girls. They could approach girls' magazines and offer to run a technology page or column especially for girls. Even running advertisements for computers, computer games or ITrelated technologies could help raise awareness of the potential of computers for girls. Print media and TV could be a powerful influence in changing the perceptions of potential IT students.

\section{Conclusion}

This research has been exploratory in nature, but the results have shown that the topic could be explored further. It would be useful to investigate a wider range of students and school children. An in-depth study into the school curriculum and the way in which that curriculum is being taught is needed to see if improvements could be made to help girls see IT as a potential career.

Negative stereotypes are detracting both male and female students away from studying IT. Changing these perceptions may require the computer profession to become more aggressive in public relations and showcasing its stars (especially female stars). Universities and schools may need to reshape their products to make them more appealing to potential students (especially girls).

\section{References}

Cameron, R. (2000). Draft program proposal: Socio-technical informatics. Retrieved 2005, August 19, from http://fas.sfu.ca/ucc/Papers/2000/2000-14/2000-14.html

Camp, T. (2002). Message from the guest editor. SIGCSE Bulletin, 34(2), 6-8.

Cottrell, J. (1992). I'm a stranger here myself: A consideration of women in computing. Proceedings of the $20^{\text {th }}$ Annual ACM SIGUCCS conference on user services, Cleveland, Ohio, United States.

deBare, I. (1996). Computer classes lack key feature: Girl's faces. Retrieved 2005, February 2 from http://www.sacbee.com/static/archive/news/projects/women/wcschools.html\#voices 
Gallivan, M., Truex, D., \& Kvasny, L. (2002). An analysis of the changing demand patterns for information technology professionals. Proceedings of the 2002 ACM SIGCPR conference on computer personnel research, 1-13.

Galpin, V.C. (2002). Retention of women in computer science. Retrieved 2005, February 12, from http://www.cs.wits.ac.za/ vashti/sem/Gal00interface.html

Holmes-Rowell, G., Phac, D, Hankins, J., Parker, B., Petter, C., \& Iriarte-Gross, J. (2003). Computer related gender differences. Retrieved 2005, September 13, from http://women.cs.cmu.edu/Resources/Campus/womenAndComputing.pdf

Jepson, A., \& Perl, T. (2002). Priming the pipeline. SIGCSE Bulletin, 34(2), 36-39.

Johnson, D.G. \& Miller, K.W. (2002). Is diversity in computing a moral matter? SIGCSE Bulletin, 34(2), 9-10.

Joshi, K. \& Kuhn, K. (2001). Gender differences in IS career choice: Examine the role of attitudes and social norms in selecting IS profession. ACM Special Interest Group on Computer Personnel Research, 121-124.

Lang, C. \& Hede, T. (2004). Gender and IT: Do stereotypes persist? In C. A. Brebbia \& A. Voiskounsky (Eds.), Human Perspectives in the Internet Society: Culture, Psychology and Gender (pp.287-296). Southampton: WIT Press.

O'Keefe, B. (2005, January 26). Australian IT: IT demand for 'soft'skills rise. The Australian.

Pearl, A., Pollack, M.E., Riskin, E., Thomas, B., Wolf, E. \& Wu, A. (2002). Becoming a computer scientist. Communications of the ACM, 34(2), 135-144.

Teague, J. (2002). Women in computing: What brings them to it, what keeps them in it? ACM SIGCSE Bulletin, 34(2), 147-158.

Victorian curriculum and assessment authority (2004). Retrieved 2005, August 12, from http://www.vcaa.vic.edu.au/prep10/csf/klas/itklas/ittechnology12.html

\section{Biographies}

Theda Thomas is a Senior Lecturer at ACU National in Melbourne, Australia. She is course coordinator for the Bachelor of Information Systems degree. Her main research interests are Information Systems Education and helping students develop the non-technical skills needed to be an IT Professional.

Alesha Allen was a Bachelor of Information Systems (Honours) student at ACU National. She completed the degree at the end of 2005. 